\title{
Alkaline phosphatase activity of polymorphonuclear leucocytes and lymphocytes separated from normal human blood
}

\author{
JUDITH K. PARK \\ From the Department of Pharmacology, University of Edinburgh, George Square, \\ Edinburgh
}

SYNOPSIS Suspensions of polymorphonuclear leucocytes and lymphocytes were prepared from normal human blood by the glass bead column method of Rabinowitz (1964). The alkaline phosphatase activity of the separated cells was determined by biochemical and cytochemical techniques.

Lymphocytes were found to contain an enzyme catalysing the hydrolysis of $\beta$-glycerophosphate at alkaline $p \mathrm{H}$ but not of p-nitrophenylphosphate at the same $p \mathrm{H}$ and in the same buffer system. The alkaline phosphatase in polymorphonuclear leucocytes catalysed the hydrolysis of both substrates equally. The importance of this finding to the interpretation of clinical data is discussed.

In 1959 Meislin, Lee, and Wasserman published a correlative study, by biochemical and cytochemical methods, of leucocyte alkaline phosphatase activity in health and disease. The cytochemical technique suggested that leucocyte alkaline phosphatase activity was restricted solely to mature neutrophils. However, when the biochemical estimate was expressed in terms of these cells the correlation between the two methods was not as good as predicted. The discrepancy was most apparent in chronic lymphatic leukaemia and acute blastic leukaemia when the cytochemical method gave low 'scores' and the biochemical estimations resulted in relatively high values. Meislin et al (1959) suggested two possible reasons for this difference. First, there might be an additional (other than mature neutrophils) enzyme source not demonstrable by cytochemical techniques but contributing to the total leucocyte alkaline phosphatase activity measured biochemically. Secondly, there might be more than one 'alkaline phosphatase' and the two techniques, because they involve different treatments of the sample, estimate different enzyme activities. There is a third possibility: variable destruction of the enzyme during the process of drying and fixing the smear.

Received for publication 25 March 1970.
In an attempt to clarify the issue I have compared two biochemical methods, employing different substrates, for measuring leucocyte alkaline phosphatase activity. Using suspensions of polymorphonuclear leucocytes and lymphocytes separated from normal human blood by the method of Rabinowitz (1964), the contribution that each cell type makes to the total enzyme activity measured can be calculated.

\section{Materials and Methods}

\section{REAGENTS}

All solutions were freshly prepared from Analar grade chemicals and glass-distilled water.

\section{CELL SUSPENSIONS}

Freshly drawn venous blood was transferred to a glass tube containing preservative-free heparin (final concentration 10 units $/ \mathrm{ml}$ blood). Sedimentation of the erythrocytes was achieved by the addition of high-molecular weight dextran (Pharmacia, mol wt 250,000). The polymorphonuclear leucocytes and lymphocytes were separated from the leucocyte-rich plasma by the 
glass bead column method of Rabinowitz (1964). The column wash-out solutions he describes were used in this work. The collected cells were washed thrice with five volumes of $0.9 \% \mathrm{NaCl}$ to remove any plasma adhering to them. Final suspensions were made in saline and the counts adjusted to $10-20,000$ polymorphonuclear leucocytes/c $\mathrm{mm}$ and $50-70,000$ lymphocytes $/ \mathrm{c} \mathrm{mm}$. The final polymorphonuclear leucocyte suspensions had a composition on average of 93 polymorphonuclear leucocytes: 7 lymphocytes: 24 erythrocytes, the corresponding figures for the lymphocyte suspensions being 9:91:890. Nucleated and red cell counts were performed in duplicate by standard haemocytometer methods. Differential cell counts were made on air-dried smears stained with Leishman stain.

\section{ESTIMATION OF LEUCOCYTE ALKALINE} PHOSPHATASE ACTIVITY

\section{Cytochemical method}

Slides for the cytochemical determinations were prepared from smears of the cell suspensions, air-dried and fixed in $10 \%$ formol-methanol. The azo-dye coupling technique described by Hayhoe and Quaglino (1958) with methyl green as counterstain was used. The slides were examined by a technician experienced in this method for estimating leucocyte alkaline phosphatase activity clinically.

\section{Biochemical methods}

The leucocyte alkaline phosphatase activity of aliquots $(0 \cdot 1-0 \cdot 2 \mathrm{ml})$ of the cell suspensions was estimated by two techniques. With the method of Valentine and Beck (1951) 0.026M sodium $\beta$-glycerophosphate, in $0.04 \mathrm{M}$ barbitone$\mathrm{HCl}$ buffer at $p \mathrm{H} 10 \cdot 0$, was used as substrate. Following enzymic hydrolysis the liberated phosphate was estimated spectrophotometrically by the method of King and Wootton (1959). Leucocyte alkaline phosphatase activity was expressed as $\mathrm{mgP} / 10^{10}$ leucocytes/hour.

Utilizing the method originally described by Bessey, Lowry, and Brock (1946), 5.5 mM sodium p-nitrophenylphosphate, in $0.05 \mathrm{M}$ glycine $-\mathrm{NaOH}$ buffer at $p \mathrm{H} 10 \cdot 5$, was used as substrate. After the incubation period the yellow colour of p-nitrophenol at alkaline $p \mathrm{H}$ was estimated spectrophotometrically. Since a single atom of phosphorus is liberated from the substrate for each molecule of p-nitrophenol the results could be converted into the same units as for the glycerophosphate method. In both procedures leucocyte alkaline phosphatase activity was always measured in duplicate. The precision of both methods was similar: the mean difference between duplicates \pm SD $(n=20)$ was $3.1 \% \pm$ $1.4 \%$ for the glycerophosphate method and $2 \cdot 8 \% \pm 1 \cdot 1 \%$ for the p-nitrophenol method.
CALCULATION OF THE ENZYME ACTIVITY OF EACH CELL TYPE

The differential cell count ( $\%$ PMN: $\% \mathrm{~L})$ and the measured leucocyte alkaline phosphatase activity were known for each cell suspension. Therefore, assuming that the enzyme activities of the two cell types are additive, two equations may be derived

$$
\begin{aligned}
& \mathrm{a} x+\mathrm{b} y=\mathrm{A}(1) \\
& \mathrm{c} x+\mathrm{d} y=\mathrm{B}(2)
\end{aligned}
$$

where $x=$ enzyme activity of polymorphonuclear leucocytes

$y=$ enzyme activity of lymphocytes

$\mathrm{a}=$ no. of polymorphonuclear leucocyte in the suspension

$\mathbf{b}=$ no. of lymphocytes in polymorphonuclear leucocyte suspension

$\mathrm{c}=$ no. of polymorphonuclear leucocytes in lymphocyte suspension

$\mathrm{d}=$ no. of lymphocytes in lymphocyte suspension

$\mathbf{A}=$ total enzyme activity of polymorphonuclear leucocyte suspension

B = total enzyme activity of lymphocyte suspension.

The values of $x$ and $y$ are obtained by solution of these equations. In each experiment the leucocyte alkaline phosphatase activity of a suspension of unseparated leucocytes was also measured. This served two purposes. First, it was possible to examine the likelihood that column separation changed leucocyte alkaline phosphatase activity. Secondly, the validity of the assumption made in the calculations and the accuracy of the subsequent results could be tested.

\section{Results}

THE GLYCEROPHOSPHATE METHOD

Blood from five haematologically normal donors was examined and the following results (in $\mathrm{mgP} / 10^{10}$ cells/hour) were obtained:

For polymorphonuclear leucocytes $13.5,23.2$, $53.5,23.5,28.0$ (mean value 28.4 ); for lymphocytes $2 \cdot 9,5 \cdot 2,9 \cdot 2,4 \cdot 6,5 \cdot 3$ (mean value $5 \cdot 4$ ); for unseparated cells $9 \cdot 2,16 \cdot 5,35 \cdot 8,18 \cdot 4,19 \cdot 3$ (mean value 19.8).

It was found that leucocyte alkaline phosphatase activity is not changed significantly by column separation and the assumption that the enzyme activities of the two cell types are additive appears to be valid. The values for the leucocyte suspensions are in agreement with those of Valentine and Beck (1951). The data suggest that lymphocytes possess some alkaline phosphatase activity (about one-fifth that of polymorphonuclear leucocytes). The observed activity of lymphocytes is not due to the erythrocytes present in the suspension; pure suspensions of 
red cells were devoid of activity when examined.

The possibility that the increase in orthophosphate during incubation does not result from enzymic hydrolysis of $\beta$-glycerophosphate was also considered. When the lymphocyte suspensions were incubated with saline in place of the substrate in the reaction mixture there was no detectable production of orthophosphate (Park, 1968). It is thus reasonable to suggest that lymphocytes do possess an enzyme capable of catalysing the alkaline hydrolysis of $\beta$-glycerophosphate.

\section{CYTOCHEMICAL DETERMINATIONS}

Representative smears of the cell suspensions used in the glycerophosphate method were examined cytochemically. Alkaline phosphatase activity was confined to the mature neutrophils in all cases; the lymphocytes were uniformly negative. On each occasion the cells were morphologically normal.

\section{THE P-NITROPHENOL METHOD}

Samples from 12 donors were examined and the following results (in $\mathrm{mgP} / 10^{10}$ cells/hour) obtained: for polymorphonuclear leucocytes mean value 28.8 (range $13.9-40 \cdot 3$ ) and for lymphocytes no significant activity. For unseparated leucocytes the mean value was 16.4 (range 8.3-22-7). These results contrast with the data from the other biochemical method. Lymphocytes apparently have no alkaline phosphatase activity although the results for both polymorphonuclear and unseparated leucocytes are normal.

The two biochemical methods differ not only in substrate but also in buffer system. Glycine is known to inhibit serum alkaline phosphatase activity, at least in high concentrations (Hausamen, Helger, Rick, and Gross, 1966). To investigate the possibility that glycine was interfering

\begin{tabular}{|c|c|c|c|c|c|c|}
\hline \multirow{2}{*}{$\begin{array}{l}\text { Cell Type } \\
\text { Substrate }\end{array}$} & \multicolumn{3}{|c|}{ Polymorphonuclear Leucocytes } & \multicolumn{3}{|c|}{ Lymphocytes } \\
\hline & $A^{2}$ & $\boldsymbol{B}$ & $\boldsymbol{C}$ & $\boldsymbol{A}$ & $\boldsymbol{B}$ & $\boldsymbol{C}$ \\
\hline $\begin{array}{l}\text { Subject } 1 \\
\text { Subject } 2 \\
\text { Subject } 3 \\
\text { Subject } 4 \\
\text { Subject } 5^{a} \\
\text { Subject } 6^{a}\end{array}$ & $\begin{array}{l}30 \cdot 6 \\
27 \cdot 8 \\
32 \cdot 2 \\
26 \cdot 9 \\
27 \cdot 6 \\
22 \cdot 4\end{array}$ & $\begin{array}{l}36 \cdot 8 \\
24 \cdot 1 \\
32 \cdot 8 \\
29 \cdot 7 \\
28 \cdot 4 \\
24 \cdot 6\end{array}$ & $\begin{array}{l}32 \cdot 3 \\
25 \cdot 0 \\
32 \cdot 3 \\
27 \cdot 3 \\
25 \cdot 4 \\
24 \cdot 0\end{array}$ & $\begin{array}{r}-1 \cdot 3 \\
0.3 \\
0.1 \\
0.1 \\
1.6 \\
-0.8\end{array}$ & $\begin{array}{l}7 \cdot 8 \\
4 \cdot 8 \\
6 \cdot 6 \\
5 \cdot 9 \\
5 \cdot 7 \\
4 \cdot 9\end{array}$ & $\begin{array}{l}6 \cdot 5 \\
5 \cdot 2 \\
6 \cdot 4 \\
5 \cdot 5 \\
5 \cdot 2 \\
4 \cdot 8\end{array}$ \\
\hline $\begin{array}{l}\text { Mean } \\
\text { SD }\end{array}$ & $\begin{array}{r}27 \cdot 9 \\
3 \cdot 4\end{array}$ & $\begin{array}{r}29.4 \\
4.9\end{array}$ & $\begin{array}{r}27 \cdot 7 \\
3 \cdot 7\end{array}$ & $\begin{array}{l}0.0 \\
1.0\end{array}$ & $\begin{array}{l}6 \cdot 0 \\
1 \cdot 1\end{array}$ & $\begin{array}{l}5.6 \\
0.7\end{array}$ \\
\hline
\end{tabular}

Table Comparison of three methods for estimating the alkaline phosphatase activity of separated polymorphonuclear leucocytes and lymphocytes 1

${ }^{1}$ Leucocyte alkaline phosphatase activity in $\mathrm{mg} \mathrm{P} / 10^{10}$ cells/hour.

'A = sodium p-nitrophenylphosphate in glycine $-\mathrm{NaOH}$ buffer; $\mathrm{B}=$ sodium $\beta$-glycerophosphate in barbitone $-\mathrm{HCl}$ buffer; $\mathrm{C}=$ sodium $\beta$-glycerophosphate in glycine $-\mathrm{NaOH}$ buffer.

'Two women with chronic lymphatic leukaemia successfully managed with chlorambucil. with any enzyme activity of lymphocytes, sodiun? $\beta$-glycerophosphate in $0.05 \mathrm{M}$ glycine buffe $\vec{F}_{0}$ at $p \mathrm{H} 10.5$ was used as substrate. A compariso was made of the two substrates and the two buffe $\bar{\sigma}$ systems and the results are shown in Table $\mathrm{L}_{\text {. }}$ It is apparent that lymphocytes contain a $\overline{\bar{m}}$ enzyme capable of catalysing the hydrolysis of $\beta$-glycerophosphate at alkaline $p \mathrm{H}$ but not of p-nitrophenylphosphate at the same $p \mathrm{H}$ and i the same buffer system. The leucocyte alkalin 8 phosphatase activity of polymorphonuclear leueo cocytes is the same whichever substrate-buffer system is used, suggesting that this enzyme shows no substrate specificity.

In addition to normal cells blood from two patients with chronic lymphatic leukaemia was examined (Table). In both cases the lymphocytes contained an enzyme catalysing the alkaline hydrolysis of $\beta$-glycerophosphate. There appears therefore, to be no difference between normas and leukaemic lymphocytes in this respect.

\section{Discussion}

The work reported in this paper suggests that mature neutrophils are not the sole source of alkaline phosphatase in blood cells and that non granulocytes can contribute significantly to the total enzyme activity measured. In addition, is has been shown that there are certain differences between the polymorphonuclear leucocyte and? the lymphocyte enzyme.

Cytochemical detection of alkaline phosphatase using sodium $\alpha$-naphthyl phosphate as substrate suggests that the enzyme is restricted to the mature neutrophils. Various biochemical tech niques show, however, that lymphocytes apparo ently contain small but significant amounts of an enzyme catalysing the hydrolysis of $\beta$-glycero phosphate at alkaline $p \mathbf{H}$ but not of p-nitro phenylphosphate at the same $p \mathrm{H}$ and in the same buffer system. The failure to detect enzyme activity cytochemically using $\beta$-glycerophosphate as substrate (Meislin et al, 1959) is puzzling and one must assume either that the enzyme is? insufficiently concentrated or that the process of drying and preparing the smears removes it The alkaline phosphatase of polymorphonucleato leucocytes-the 'classical' leucocyte alkaline phosphatase-does not show substrate specificity and estimates by both biochemical techniques? are in good agreement. It is thus unlikely thato the enzyme activity in lymphocytes is a pro cedural artefact or that it reflects errors in the method.

Tietz, Woodrow, and Woodrow (1966) com pared the methods of Bodansky (using $\beta \leqslant$ glycerophosphate) and of Bessey et al (1946\$ (using p-nitrophenylphosphate) for estimating serum alkaline phosphatase activity. They cono cluded that there was only an approximate 
relationship between the values obtained by both methods and that it is invalid to use a factor to convert units of one method into units of the other. Tietz et al attributed the lack of correlation to the different substrate specificities of the various phosphatases in serum. Robinson, Pierce, Goldstein, and Rosse (1966) have examined leucocyte alkaline phosphatase isozymes by starch-gel electrophoresis and found three bands in the normal. Leucocyte alkaline phosphatase is thus not a single protein but is composed of at least three with different electrophoretic mobilities. Whether these isoenzymes have different substrate specificities, as is the case with serum alkaline phosphatase, has not been established. The electrophoretic pattern of extracts of pure suspensions of polymorphonuclear leucocytes and lymphocytes is also unknown.

If one defines alkaline phosphatase as an enzyme catalysing the hydrolysis of a phosphomonoester at alkaline $p \mathrm{H}$ then there certainly seems to be evidence, from this work, that lymphocytes possess such an enzyme. Although the amount of enzyme in the lymphocyte is small compared with that in the neutrophil, lymphocytes will contribute significantly to the total enzyme activity measured with sodium $\beta$ glycerophosphate as substrate. Since the activity is so low the failure to detect it cytochemically probably results from insufficient localization of the enzyme within the cell.

The observation that the lymphocytes of chronic lymphatic leukaemia also possess alkaline phosphatase activity is of considerable interest. Only two patients, both being successfully managed with chlorambucil, were examined; a more extensive study is clearly indicated.

The assumption that mature neutrophils are the only source of alkaline phosphatase in blood cells is based on cytochemistry; evidence of a non-granulocytic source, as presented here, became possible as the result of the successful separation of normal polymorponuclear leucocytes from normal lymphocytes. In a leucocyte suspension consisting of $60 \%$ polymorphonu- clear leucocytes and $40 \%$ lymphocytes the $\stackrel{\varrho}{=}$ contribution by the latter cells to the total $\vec{\partial}$ enzyme activity will only be 10 to $15 \%$. This contribution will, however, be very much higher when lymphocytes form the bulk of the population. Thus in chronic lymphatic leukaemia with $\stackrel{9}{\stackrel{5}{2}}$ a differential of $20 \%$ polymorphonuclear leuco- $\bar{O}$ cytes: $80 \%$ lymphocytes the contribution will be approximately $50 \%$. Obviously the method of $\frac{\omega}{2}$ Valentine and Beck is unsuited for estimations of $\frac{\mathbb{D}}{\alpha}$ the leucocyte alkaline phosphatase activity of neutrophils under these circumstances.

The author wishes to thank Professor W. L. M. Perry and Dr S. H. Davies for advice and encouragement throughout this work.

\section{References}

Bessey, O. A., Lowry, O. H., and Brock, M. J. (1946). A method for the rapid determination of alkaline phosphatase with five cubic millimetres of serum. J. biol. Chem., 164, 321329.

Hausamen, T.-U., Helger, F., Rick, W., and Gross, W. (1966). Optimal conditions for the determination of serum alkaline phosphatase by a new kinetic method. Clin. chim. Acta, $\mathbb{D}$ 15, 241-245.

Hayhoe, F. G. J., and Quaglino, D. (1958). Cytochemical demon- $\overrightarrow{6}$ stration and measurement of leucocyte alkaline phospha- $\supset$ tase activity in normal and pathological states by a modified azo-dye coupling technique. Brit. J. Haemat., 4, 375-389.

King, E. J., and Wootton, I. D. P. (1964). Micro-analysis in Medical Biochemistry, 4th ed. Churchill, London.

Meislin, A. G., Lee, S. L., and Wasserman, L. R. (1959). Leukocyte alkaline phosphatase activity in hematopoietic disorders. (A correlative study by biochemical and cytochemical techniques.) Cancer (Philad.), 12, 760-766.

Park, J. K. (1968). Some aspects of leucocyte and bone marrow cell metabolism in vitro: the effects of drugs which induce agranulocytosis. $\mathrm{PhD}$ Thesis, Edinburgh University.

Rabinowitz, Y. (1964). Separation of lymphocytes, polymorphonuclear leukocytes and monocytes on glass columns, including tissue culture observations. Blood, 23, 811-828.

Robinson, J. C., Pierce, J. E., Goldstein, D. P., and Rosse, W. R. (1966). Leucocyte-alkaline-phosphatase isozymes. Lancet, 2, 805.

Tietz, N. W. Woodrow, D., and Woodrow, B. (1966). A comparative study of the Bodansky and the Bessey, Lowry and Brock methods for alkaline phosphatase in serum. Clin. chim. Acta, 15, 365-367.

Valentine, W. N., and Beck, W. S. (1951). Biochemical studies on leucocytes. 1. Phosphatase activity in health, leucocytosis and myelocytic leucemia. J. Lab. clin. Med., 38, 39-55. 